\title{
ROLLO DAVIDSON TRUST
}

At a meeting of the Trustees on 11 April 1985 Rollo Davidson Prizes were awarded to

Piet Groeneboom of the Centre for Mathematics and Computer Science, Amsterdam, The Netherlands, for his work on brownian motion with a parabolic drift, and to

Terence John Lyons, Colin Maclaurin Professor of Pure Mathematics in the University of Edinburgh, Scotland, for his work on chainmanifold correspondences and on the spectral discrimination of boundedly related riemannian metrics.

The first Rollo Davidson Prize was awarded in 1976, and fourteen prizes in all have now been awarded. The work of the Trust is supported by the gift of royalties, and by individual donations. Correspondence should be addressed to its Secretary: The Bursar, Churchill College, Cambridge, CB3 0DS, UK. 


\section{Advances in Applied Probability}

The Editorial Board would like to encourage the submission to the Advances of review papers summarising and coordinating recent results in any of the fields of applied probability.

In addition to these review papers, Advances is also designed to be a medium of publication for (1) longer research papers in applied probability, which may include expository material, (2) expository papers on branches of mathematics of interest to probabilists, (3) papers outlining areas in the biological, physical, social and technological sciences in which probability models can be usefully developed, (4) papers in applied probability presented at conferences which do not publish their proceedings, and finally, (5) letters to the editor on any appropriate topic in applied probability.

In short, the main function of Advances is to define areas of recent progress and potential development in applied probability. As with the Journal of Applied Probability, Advances undertakes to publish papers accepted by the Editors within 15 months of their submission; letters to the editor will normally be published more rapidly.

The Editor-in-Chief is J. Gani; the Coordinating Editors are C. C. Heyde, M. F. Neuts and G. E. H. Reuter; other editors are P. J. Brockwell, V. R. Cane, J. W. Cohen, E. J. Hannan, J. Keilson, D. G. Kendall, J. F. C. Kingman, K. Krickeberg, R. M. Loynes, K. R. Parthasarathy, C. A. B. Smith, and R. L. Tweedie. The Editorial Office of the Advances is in the Department of Probability and Statistics, The University, Sheffield S3 7RH, England.

Volume 17 No. 3 of Advances contains the following papers:

GIANPAOLO SCALIA-TOMBA. Asymptotic final-size distribution for some chain-binomial processes

THOMAS A. DARDEN AND MICHAEL A. RESNICK. DNA fragment mass distributions following molecular recombination

E. A. VAN DOORN. Conditions for exponential ergodicity and bounds for the decay parameter of a birth-death process

R. MITCHELL COX AND IOANNIS KARATZAS. Stationary control of Brownian motion in several dimensions

EMMANUEL YASHCHIN. On a unified approach to the analysis of two-sided cumulative sum control schemes with headstarts

ORA E. PERCUS. Phase transition in one-dimensional random walk with partially reflecting boundaries

LEON WILLENBORG. The thrown string: a Markov field approach

PAUL EMBRECHTS, JENS L. JENSEN, MAKOTO MAEJIMA AND J. L. TEUGELS. Approximations for compound Poisson and Pólya processes

ESPEN FUNNEMARK AND BENT NATVIG. Bounds for the availabilities in a fixed time interval for multistate monotone systems

K. S. CHAN AND H. TONG. On the use of the deterministic Lyapunov function for the ergodicity of stochastic difference equations

Subscription rates (per volume) for the Advances in 1985 are the same as for the Journal (see inside back cover). A discount of $10 \%$ is allowed to subscribers who order current issues of both the Journal and Advances at the same time direct from the Applied Probability Office. A detailed price list for both current and back issues is available on request.

Cheques made out on U.S., U.K. and Australian banks will be acceptable: they should be made payable to Applied Probability, and sent to:

Executive Editor, Applied Probability,

Department of Probability and Statistics,

The University, Sheffield S3 7RH, England. 


\title{
PERSPECTIVES IN PROBABILITY AND STATISTICS
}

\section{Papers in honour of M. S. Bartlett on the occasion of his sixty-fifth birthday}

\author{
Editor: J. GANI
}

\section{Contributors}
P. Armitage
N. T. J. Bailey
G. A. Barnard
A. Blanc-Lapierre
V. R. Cane
W. G. Cochran
J. W. Cohen
D. R. Cox

Pp. viii +423

\author{
H. Cramér \\ H. E. Daniels \\ J. Gani \\ U. Grenander \\ J. M. Hammersley \\ E. J. Hannan \\ D. G. Kendall \\ J. F. C. Kingman
}
A. M. Kshirsagar
T. Lewis
P. D. M. Macdonald
P. Meier
P. A. P. Moran
C. R. Rao
C. A. B. Smith
H. Solomon

L. Takács

P. Tautu

D. Vere-Jones
P. Whittle

E. J. Williams

H. Wold

This book was published by the Applied Probability Trust in 1975 as a tribute to Professor Bartlett from colleagues throughout the world. Due to difficulties in storing the remaining stock, we are now making copies available to our readers and subscribers at only $£ 3.50$ (US\$5.00; $\$ A .6 .00$ ) to cover administrative costs, postage and packing. Please order your copy now from

\section{Applied Probability Office, Department of Probability and Statistics, \\ The University, Sheffield S3 7RH, England.}

Remittances to 'Applied Probability', please.

'..... there is variety and imagination in this volume.... Through their enthusiasm and ingenuity these $\mathbf{3 0}$ authors have provided a fitting tribute to a master.'

\section{David Hinkley in Science}

'The text is a delight to read, and several of the papers are gems in their own right..... it contains many stimulating ideas for potential research students.'

\section{Eric Renshaw in British Book News}

'.... there are substantial original contributions and magisterial summaries of important areas of knowledge.... The volume is a pleasure to browse in. It has benefitted from careful editing and production.'

$$
\text { John Hajnal in JRSS A }
$$




\section{ESSAYS IN STATISTICAL SCIENCE}

In 1982 the Applied Probability Trust issued a supplementary volume No. 19A of the Journal of Applied Probability (JAP). Entitled Essays in Statistical Science, this book consists of a collection of papers on a range of topics including statistical theory, stochastic processes, time series, geometric probability and mathematical genetics. It was published as a Festschrift in honour of the sixty-fifth birthday of Professor P. A. P. Moran FAA, FRS, of the Department of Statistics, Australian National University, Canberra, an editor of JAP from 1964 to 1982 .

This special volume is edited by J. Gani and E. J. Hannan and contains contributions from the following colleagues and students of Professor Moran: M. S. Bartlett, B. Benjamin, V. Cane, H. Cohn, D. J. Daley, H. E. Daniels, A. W. Davis, P. Erdös, W. J. Ewens, P. D. Finch, J. Gani, J. M. Hammersley, E. J. Hannan, A. M. Hasofer, C. R. Heathcote, C. C. Heyde, D. G. Kendall, J. F. C. Kingman, R. McNamee, D. R. McNeil, R. J. Maillardet, R. E. Miles, B. H. Neumann, M. Osborne, D. K. Pickard, D. Pollard, B. C. Rennie, E. L. Scott, E. Seneta, C. A. B. Smith, D. Vere-Jones, I. Vincze, G. S. Watson, G. A. Watterson, M. Westcott, P. Whittle, E. J. Williams and S. R. Wilson.

Essays in Statistical Science is in the usual JAP format $(250 \times 170 \mathrm{~mm})$; with 434 pages, and has an attractive dust jacket and hard binding. The price is $£ 18.00$ (US\$26.00; \$A28.00). Orders should be sent to the Executive Editor, Applied Probability, Department of Probability and Statistics, The University, Sheffield S3 7RH, England. 


\section{ESSAYS IN TIME SERIES AND ALLIED PROCESSES}

In January 1986 the Applied Probability Trust will publish a supplementary volume 23A of the Journal of Applied Probability (JAP) to mark the sixty-fifth birthday of Professor E. J. Hannan, an editor of the Journal since its inception in 1964. Entitled Essays in Time Series and Allied Processes, this book will consist of papers relating to various aspects of time series, Professor Hannan's main area of research. The seven sections will be devoted to: structure and general methods, estimation, hypothesis testing and distribution theory, non-linear and non-stationary systems, random fields and point processes, allied stochastic processes, and algorithms and computations.

This special volume, which is edited by J. Gani and M. B. Priestley, contains contributions from the following colleagues and students of Professor Hannan:
An Hong-Zhi
J. Henstridge
M. R. Osborne
G. K. Smyth
C. F. Ansley
S. M. Heravi
T. Ozaki
V. Solo
M. S. Bartlett
C. C. Heyde
E. Parzen
T. P. Speed
P. Bloomfield
Y. Hosoya
J. H. W. Penm
K. Tanaka
D. R. Brillinger
R. H. Jones
M. B. Priestley
R. D. Terrell
M. A. Cameron
K. Katsura
B. G. Quinn
P. J. Thomson
Chen Zhao-Guo
R. Kohn
J. Rissanen
P. Tin
M. Deistler
P. A. P. Moran
P. M. Robinson
J. G. Veitch
J. Durbin
D. F. Nicholls
M. Rosenblatt
J. Gani
Y. Ogata
R. Shibata
G. S. Watson
P. Whittle

A complete bibliography of Professor Hannan's publications from 1955 to 1984 will be included.

Essays in Time Series and Allied Processes will be in the usual JAP format $(250 \times 170 \mathrm{~mm})$ with 437 pages, but will have hard binding and an attractive dust jacket. The prepublication price is $£ 27.00$ (US\$31.50; $\$$ A.38.70); after publication the price will be $£ 30.00$ (US\$35.00; $\$ A .43 .00$ ).

This special volume may be ordered at any time, but to qualify for the prepublication price, subscribers must send a full remittance direct to Sheffield (i.e. not through a subscription agent) to arrive not later than 1 December 1985. Orders should be addressed to the Executive Editor, Applied Probability, Department of Probability and Statistics, The University, Sheffield S3 7RH, England. Remittances must be in favour of 'Applied Probability': sterling cheques should be drawn on a British bank, US or Australian dollar cheques on a US or Australian bank respectively. 


\section{SUBSCRIPTION RATES}

Subscription rates (post free) for the 1985 volume of the Journal are as follows:

Subscribers in North, Central and South America, and Australia:

US\$99.00; \$A108.00; $£ 69.00$ for libraries and institutions;

US $\$ 33.00 ; \$ A 36.00 ; £ 23.00$ for individuals belonging to a recognised scientific society.

\section{All other subscribers:}

$£ 57.00$ for libraries and institutions;

$£ 19.00$ for individuals belonging to a recognised scientific society.

Members of the London Mathematical Society should apply direct to the Secretary of the Society for copies of the Journal.

All enquiries about the Journal, as well as other subscriptions, should be sent to the Executive Editor, Miss M. Hitchcock, Department of Probability and Statistics, The University, Sheffield S3 7RH, England. The price of back numbers varies from volume to volume, and enquiries should be sent to the Executive Editor. Cheques, money orders, etc. should be made out to Applied Probability; cheques on U.S., U.K. and Australian banks will be acceptable.

\section{NOTES FOR CONTRIBUTORS}

Papers published in the Journal are of two kinds:

(1) research papers not exceeding 20 printed pages;

(2) short communications of a few printed pages in the nature of notes or brief accounts of work in progress.

Review papers, longer research papers and letters to the editor are published in Advances in Applied Probability, a companion journal. (Note: Letters relating specifically to papers which have appeared in the Journal of Applied Probability will continue to appear in the Journal.)

The editors may publish accepted papers in either journal, according to the space available, in order to meet the 15-month deadline in publication referred to below.

\section{Submission of papers}

It is a condition of publication in the Journal of Applied Probability that papers shall not previously have appeared elsewhere, and will not be reprinted without the written permission of the Trust. It is the policy of the Journal not to accept for publication papers which cannot appear in print within 15 months of the date of receipt of the final version. Authors will receive 50 reprints of their papers free, and joint authors a proportional share of this number. Additional reprints will be provided at cost.

Papers should be written in English or French; papers in other languages may be accepted by the editors, but will appear (subject to the author's agreement) in English or French translation in the Journal. Scripts should be typewritten, using double spacing, and at least one copy should be on one side of the paper only. Each paper should be accompanied by

(i) a short abstract of approximately 4-10 lines giving a non-mathematical description of the subject matter and results;

(ii) a list of keywords detailing the contents for the purpose of computerised information retrieval.

Authors are advised to consult The Author's Guide to the Applied Probability Journals when preparing papers for submission. A copy of this guide may be obtained on application to the Applied Probability Office.

For efficiency in processing, authors are requested to send three copies of all submissions to the Applied Probability Office in Sheffield, rather than to individual editors. Authors overseas are asked to ensure that their submissions are sent by airmail. The Editor-in-Chief and the Applied Probability Office are in regular contact and full details of all papers submitted are available to Professor Gani at the University of California at Santa Barbara.

\section{Copyright}

The copyright of all published papers shall be vested in the Trust. When a paper is accepted for publication, the Trust requests the author(s) to sign a form assigning copyright to the Trust. Failure to do this promptly may delay or prevent publication.

Authorisation to photocopy items for internal or personal use, or the internal or personal use of specific clients, is granted by the Applied Probability Trust for libraries and other users registered with the Copyright Clearance Center (CCC) Transactional Reporting Service, provided that the base fee of $\$ 00.50$ per copy, plus .10 per page is paid directly to CCC, 21 Congress St., Salem, MA 01970, U.S.A. $0021-9002 / 85 \$ 00.50+.10$. 


\section{Volume 22 Number 3}

\section{Research Papers}

487 ROCCO BALLERINI AND SIDNEY RESNICK. Records from improving populations

503 HELMUT PRUSCHA. Parametric inference in Markov branching processes with timedependent random immigration rate

518 LUIS-M. CRUZ-ORIVE. Estimating volumes from systematic hyperplane sections

531 D. J. GATES AND M. WESTCOTT. Accurate and asymptotic results for distributions of scan statistics

543 WILLIAM P. MCCORMICK. Weak and strong law results for a function of the spacings

$556 \mathrm{~J}$. VAN DEN BERG AND H. KESTEN. Inequalities with applications to percolation and reliability

570 MARY G. LEITNAKER AND PETER PURDUE. Compartmental models with transfer delays: a semi-Markov approach

583 P.-C. G. VASSILIOU AND I. GERONTIDIS. Variances and covariances of the grade sizes in - manpower systems

598 RAINER DAHLHAUS. On a spectral density estimate obtained by averaging periodograms

611 A. G. NOBILE, L. M. RICCIARDI AND L. SACERDOTE. Exponential trends of firstpassage-time densities for a class of diffusion processes with steady-state distribution

619 WARD WHITT. Uniform conditional variability ordering of probability distributions

634 ANDERS MARTIN-LÖF. A limit theorem which clarifies the 'Petersburg Paradox'

644 MITSUSHI TAMAKI. Adaptive approach to some stopping problems

653 A. G. DE KOK. Asymptotic analysis for a production-inventory control model with renewal arrivals and exponential demands

668 PYKE TIN. A queueing system with Markov-dependent arrivals

678 A. DVUREČENSKIJ AND G. A. OSOSKOV. On a modified counter with prolonging dead time

688 A. G. DE KOK AND H. C. TIJMS. A queueing system with impatient customers

697 WOLFGANG STADJE. The busy period of the queueing system $M / G / \infty$.

\section{Short Communications}

705 RUDOLF GRÜBEL. Tail behaviour of ladder-height distributions in random walks

710 ROLF SCHNEIDER. Inequalities for random flats meeting a convex body

717 URI LIBERMAN. An order statistic characterization of the Poisson renewal process

723 TERJE AVEN. Upper (lower) bounds on the mean of the maximum (minimum) of a number of random variables

729 DONALD W. K. ANDREWS. A nearly independent, but non-strong mixing, triangular array

732 PAULO RENATO DE MORAIS. Optimal design of a storage system with constant or linear release rate

739 MICHAEL PINEDO AND ZVI SCHECHNER. Inequalities and bounds for the scheduling of stochastic jobs on parallel machines

745 Correction

Published by the Applied Probability Trust in association with the London Mathematical Society (C) 1985 ISSN 0021-9002 